LBL-12604

UC-41

\section{ANNUAL ENVIRONMENTAL MONITORING REPORT \\ OF THE \\ LAWRENCE BERKELEY LABORATORY}

1980

Prepared by the staff of the Engineering and Technical Services Division

Lawrence Berkeley Laboratory

University of California

Berkeley, California 94720

Editor: Gary E. Echleimer

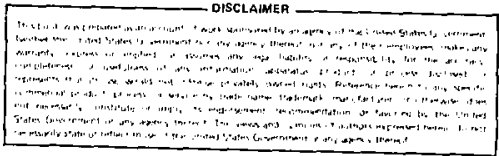

This work was supported by the Ass istant Secretary for Environment, office of Environmental Compliance and Overview,

Environmental Safety and Program Support Division of the U.S. Department of Energy under Contract No. W-7405-ENG-48. 


\section{PREFACE}

In 1976, R. H. Thomas published the LBL Annual Environmental Monitoring Report in two parts. Part I, LBL-4678, discussed in detail the modeling used to determine the population dose equivalent due to Laboratory operations. That volume also described natural radiation background, geological features, climate and meteorology, and the environmental surveillance program of the Lawrence Berkeley Laboratory. Part II, LBL-4827, included only the results of the sampling and measuring programs and other data necessary to determine the environmental impact of Laboratory operations for 1975. A format similar to LBL-4827 was used in the 1976, 1977, 1978, and 1979 Annual Monitoring Reports (LBL-6405, 7530, 9080 , and 11192, respectively).

This year, while the presentation remains brief, abstracted sections from LBL-4678 were included so that the 1980 Annual Monitoring Report might "stand alone."

Those readers wishing a more comprehensive discussion of LBL site characteristics and population dose modeling, may obtain a copy of LBL-4678 fram:

Gary E. Schleimer Environmental Health and Safety Department

Building 75, Room 113 Lawrence Berkeley Laboratory 1 Cyclotron Road

Berkeley, California 94720 
The following staff of the Environmental Health and Safety Department of the Engineering and Technical Services Division have contributed to the preparation of this report:

H. P. Cantelow

R. Pauer

G. E. Schleimer

A. R. Smith 
TABLE OF CONTENTS

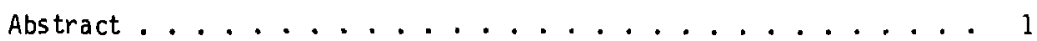

Introduction ..................... 1

1980 Environmental Monitoring Summary. . . . . . . . . . 3

Environmental Monitoring Results ..............4 4

Accelerator Produced Radiation............. 4

Airborne Radionuclides. ............... 7

Wa terborne Radionuclides. . . . . . . . . . . 14

Nonradioactive Pollutants ............... 17

Population Dose Resulting from LBL Operations. . . . . . . . 20

Accelerator-Produced Radiation. . . . . . . . . 20

Airborne Radionuclides. ............... . 21

Trends - LBL's Environmental Impact. . . . . . . . . . . 23

Accelerator Produced Radiation. . . . . . . . . . 23

Air and Waterborne Radionuclides. . . . . . . . . 23

References................... 28

Distribution List. . . . . . . . . . . . . 29 
ANNUAL ENVIRONMENTAL MONITORING REPORT

OF THE

LAWRENCE BERKELEY LABORATORY, 1980

ABSTRACT

The Environmental Monitoring Program of the Lawrence Berkeley Laboratory is described. Data for 1980 are presented and general trends दre discussed.

\section{INTRODUCTION}

Lawrence Berkeley Laboratory (LBL) is a large, multifaceted research laboratory which conducts programs of pure and applied research in the physical, biological, and environmental sciences. LBL, birthplace of the cyclotron, will celebrate its 50th anniversary in October 1981.

The Laboratory is located on the western slopes of coastal hills, east of the Berkeley campus of the University of California, between the 350 and 1,000-foot elevation contours. The site (Figs. 1 and 2) enjoys Mediterranean climate, an annual rainfall of 24.3 inches (22-year average), predominately northwesterly winds during traditionally dry summers, and southerly breezes during storms. LBL's hilly perimeter straddles two shallow canyons which contain the wellsprings of Strawberry and Blackberry creeks. The population within a $50 \mathrm{mile}(80 \mathrm{~km})$ radius of the Laboratory is approximately $4.6 \mathrm{mill}$ ion (1970 census); this includes most of the residents of the greater metropolitan San Francisco bay area. 
LBL research facilities include: four large accelerators, a number of radiochemical laboratories, and a tritium (H-3) labeling lab. The Bevatron (Building 6, Fig. 1) is the most massive of LBL's accelerators. Originally designed as a $6 \mathrm{GeV}$ proton synchroton, the Bevatron is presently used to accelerate light and medium mass nuclei to energies up to 2 to $3 \mathrm{GeV}$ per nucleon. The SuperHILAC (Building 71), a heavy ion linear accelerator, is used to produce ion beams of energies up to $8 \mathrm{MeV}$ per nucleon. A multiprogrammable research accelerator in its own right, the SuperHILAC doubles as an injector for the Bevatron. The 88-inch sector-focused cyclotron (Building 88) produces intense beams of light and medium mass nuclei to energies on the order of $100 \mathrm{MeV}$. The 184-inch cyclotron (Building 6) provides alpha particle beams with energies up to $-1 \mathrm{GeV}$. The first three of the four accelerators described above provide beams for a variety of research applications around the clock; the 184-inch cyclatron is run only for brief perioc: during the week and is operated mainly for tumor therapy. The Tritium Facility located in Building 75 was designed to handle kilocurie quantities of tritium ised as a labeling agent for a variety of molecules subsequentiy employed in chemical anc :iomedical research. Radiochemical and radiobiological studies performed in many laboratories at LBL typically use millicurie quantities of a variety of radionuclides. The workplaces and effluent release points of all installations at LBL, where significant quantities of radionuclides are handled, are continuously sampled. 
1980 ENVIRONMENTALL MONITORING SUMMAR̃Y

In order to establish whether LBL research activities produced any impact on the population surrounding the Laboratory, a program of environmental air and water sampling and continuous radiation monitoring was carr ied on throughout the year. ${ }^{1}$ For $C Y 1980$, as in the previous several years, doses attributable to LBL radiological operations were a smal? fraction of the relevant radiation protection guidelines (RPG). ${ }^{2}$

The maximum dose delivered to a member of the community was less than 4.0 mRem (the 1980 dose equivalent measured at the 01ympus Gate monitoring station B-13D, about $0.8 \%$ of the RPG. The total population dose equivalent attributable to LBL operations during CY 1980 was $\leq 4.5$ man-rem, about $0.0006 \%$ of the RPG of $170 \mathrm{mRem} / \mathrm{pers}$ on to a suitable sample of the population.

On the evening of May 15, 1980, a fire occurred in a hood in a radiochemical laboratory in Building 70A, rasulting in an airborne release of $1.7{ }_{\mu} \mathrm{Ci}$ of ${ }^{243} \mathrm{Cm}$. This incident, prompt $1 \mathrm{y}$ reported to $\mathrm{DOE}$, was reviewed in the lccal media. Onsite sumples in an adjacent Building 70 contained detectable levels of ${ }^{243} \mathrm{Cm}$, but activity on perimeter environmental samples remained with in the range of normal background.

The People's Republic of China conducted an atmospheric nuclear test on or about October 15, 1980. Slightly elevated levels of gross-beta activity were found in weekly environmental air samples from early November th the end of the year. Gamma analysis of the samples revealed small quantitites of several-week-old mixed fission fragments, predominately ${ }^{95} \mathrm{Zr} / \mathrm{Nb},{ }^{103} \mathrm{Ru}$, and ${ }^{141} \mathrm{Ce}$. Maximum concentration of the fission products reached $0.2 \times 10^{-12} w \mathrm{Ci} / \mathrm{ml}$ (Maximum activity was found on samples removed December 16, 1980). 


\section{ENVIRONMENTAL MONITORING RESULTS}

\section{ACCELERATOR-PROOUCED RAOIATION}

To determine the radioinaical impact of LBL accelerator operations, we maintain permanent monitoring stations at four points about LBL's perimeter (see Fig. 1 and Table 1).

Table 1. Location of LBL monitoring stations.

Fig. 1 Bldg. Designation

"Common Name"

$\begin{array}{ll}\text { B-13 A } & \text { Bldg. } 88 \text { Environmental M. S. } \\ \text { B-13 B } & \text { Bldg. } 90 \text { Environmental M. S. } \\ \text { B-13 C } & \text { Panoramic Environmental M. S. } \\ \text { B-13 D } & \text { 0lympus Gate Environmental M. S. }\end{array}$

Fach station contains sensitive neutron and gamma pulse counters. The neutron detectors are $\sim 800 \mathrm{~cm}^{3}$ cylindrical $\mathrm{BF}_{3}$ chambers housed in 2-1/2" thick cylindrical paraffin moderators. The gamma detectors are energy-compensated Geiger-Muller chambers. The output pulses from each of the eight detectors (one of each type is installed at each monitoring station) are prescaled and telemetered to registers in Building $75 .^{4}$ Each LBL accelerator building contains at least one somewhat smaller moderated $\mathrm{BF}_{3}$ neutron detector whose output pulses are also prescaled and telemetered to Building 75. Operational checks of the system are performed daily, and detectors are calibrated semiannually. Typical dose per "tick" value for a perimeter monitoring station neutron detector is $0.47{ }_{\mu R e m} /$ tick. A gamma detector tick is about $1.4{ }_{\mu} R$. 


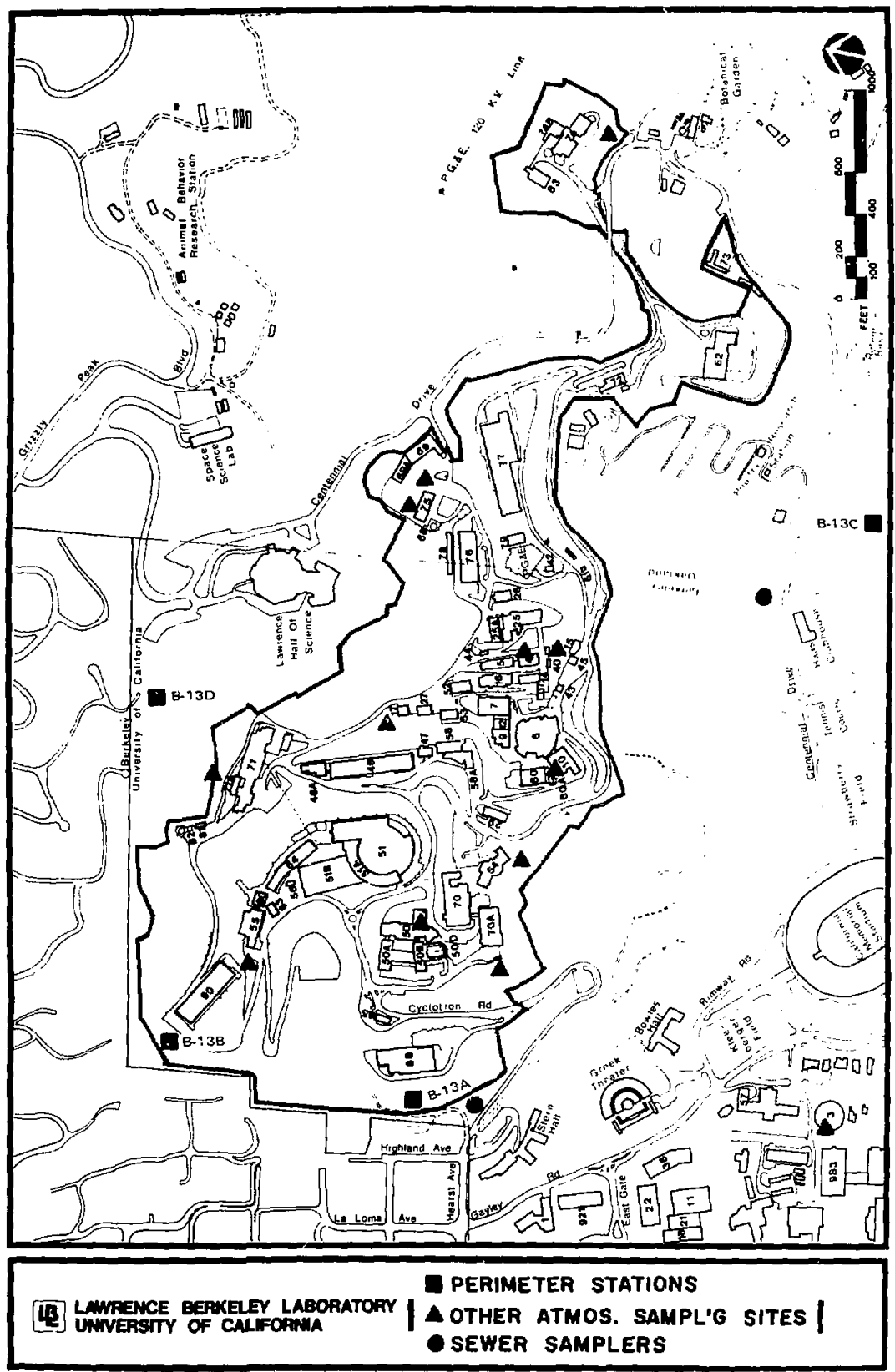


The neutron background attributable to cosmic rays measured at LBL exhibits small fluctuations about a mean value of $3.3 \mathrm{mRem} /$ year. ${ }^{3}$ Table 2 1 ists the fence post doses measured at each environmental monitoring station during 1980.

The fence-post ncutron fluence attributable to LBL accelerator operation for 1980 is characterized as follows:

(a) The 184-inch cyclotron produced a small measurable fence post dose (Panoramic M. S. data, Table 1);

(b) The SuperHILAC and Bevatron contributed equally to the dose measured at the 01 ympus Gate M. S., a dose generally uniformly delivered during the operating year.

(c) The 88-inch cyclotron dose ( $81 \mathrm{dg}, 88$ M. S. data) was also rather uniformly distributed throughout the beam year with the -xceptinn of one 100-hour ${ }^{3} \mathrm{He}$ run, which produced a dose of $0.44 \mathrm{mRem}$, and 19 short, intense proton beam runs responsible for a total dose of $0.8 \mathrm{mRem}$.

(d) The Building $90 \mathrm{M}$. S. dose was correlated with and is attributed to 88 -inch cyclotron operations.

The continuous gamma measurements telemetered from three of the four perimeter stations demonstrated no significant correlation with the operation of any of the LBL accelerators and were background for 1980 . The mean value of gamma background for the three stations was $80 \pm 5 \mathrm{mR}$ for the year. The gamma channel from Panoramic M. S. failed to produce cons is tently reliable data in 1980 and is nat reported here. 
Table 2. Radiation dose at the LBL boundary due to accelerator operation, 1980.

\begin{tabular}{llll}
\hline \multicolumn{1}{c}{ Station } & \multicolumn{1}{c}{1980 Total above background } \\
\cline { 2 - 4 } & $\gamma$ (mrem) & $n$ (mrem) & Totala (mrem) \\
\hline 01ympus Gate M. S. & Background & 4.0 & $4.0 \pm 0.11$ \\
Building 90 M. S. & Background & 1.1 & $1.1 \pm 0.1$ \\
Building 88 M. S. & Background & 3.7 & $3.7 \pm 0.12$ \\
$\begin{array}{l}\text { Panoramic M. S. } \\
\text { Standard for comparisonb } \\
\text { (Dose to individuals at the maximum point of exposure) }\end{array}$ \\
\hline
\end{tabular}

aThe errors shown are those associated with the actual counts.

Dose conversion factors are not known to this accuracy.

bSource: Reference 2.

\section{AIRBORNE RADIONUCLIDES}

Gross atmospheric beta and alpha are measured by air sampling at 14 points, 4 perimeter environmental monitoring stations, and at 10 of the 12 other atmospheric sampling sites identified in Figure 2. (The site on the north side of Building 75 is a rain collector; the Building 3 site contains samplers for HTO[tritriated water] and ${ }^{14} \mathrm{CO}_{2}$ ).

The gross beta and alpha sampling medium is a 4 in. by 9 in. celluloseasbestos filter through which air is pumped at four cfm. Samples are changed weekly and set aside for five days. This enables short-lived radon and thorium daughters, naturally occurring airborne radionuclides, to decay out of the samples before counting. The filters are loaded 


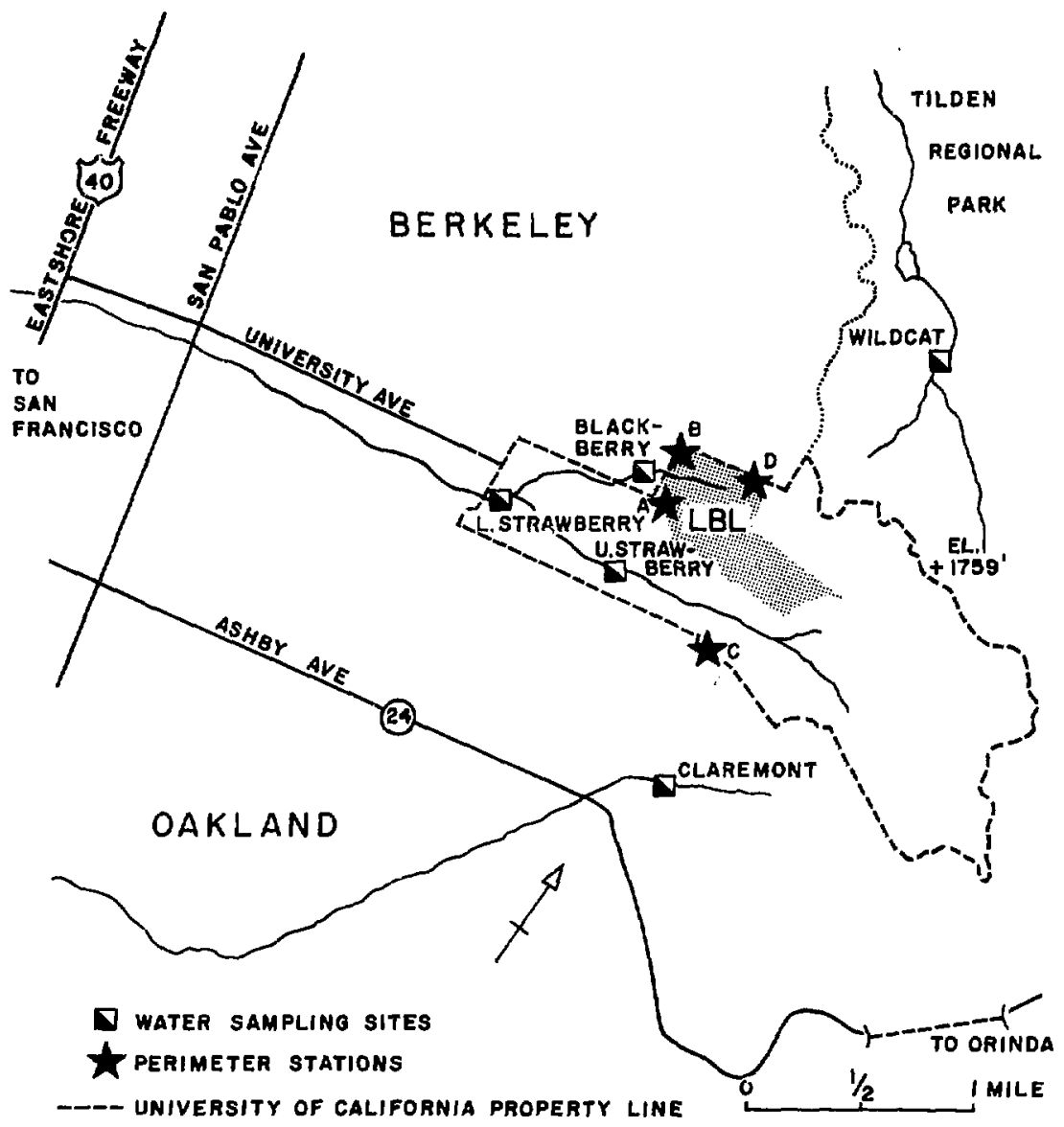

ENVIRONMENTAL MONITORING

LAWRENCE BERKELEY LABORATORY

BERKELEY, CALI FORNIA 
into an automatic counter "which determines their gross-alpha activity by means of a large area, $0.25 \mathrm{mil}$ mylar window, gas-proportional counter. Gross-beta is counted with $2-30 \mathrm{mg} / \mathrm{cm}^{2}$, window Geiger-Muller detectors. The detection limit for ilpha emitters is $2 \times 10^{-15}{ }_{\mu} \mathrm{Ci} / \mathrm{ml}$; the limit for beta emitters is $80 \times 10^{-15} \mu \mathrm{Ci} / \mathrm{ml}$.

Tritium, as HTO, is sampled by passing atmospheric air through a column containing silica gel. Adsorbed water is "exchanged" into distilled water and an aliquot $(5 \mathrm{ml})$ is placed in a vial and counted in a scintillation counter. The detection limit for $\mathrm{HiO}$ in air is $700 \times 10^{-12}{ }_{\mu \mathrm{Ci}} / \mathrm{mr}$.

As with gross alpha and beta samples, silica gel HTO samples are changed week $1 y$. Each of the four perimeter environmental monitoring stations contains a tritium sampler, as does the Building 3 site (the stack from the tritiun labeling facility is also monitored for tritium as described above).

The concentration of ${ }^{14} \mathrm{CO}_{2}$ in air is determined by air sampling with $\mathrm{NaOH}$; samples are changed weekly. Air is bubbled through a jar containing $30 \mathrm{ml}$ of $0.2 \mathrm{~N} \mathrm{NaOH}$, and thymol blue as a $\mathrm{pH}$ indicator. If acid fumes in the sampled air drop the $\mathrm{pH}$ of the sample to about 5 , a color change results, and the sample is assumed to be invalid. An aliquot $(5 \mathrm{ml}$ ) of the $\mathrm{NaOH}$ is added to scintillation cocktail and counted in a liquid scintillation counter. The detection limit for ${ }^{14} \mathrm{CO}_{2}$ is $200 \times 10^{-12} \mu \mathrm{Ci} / \mathrm{ml}$.

The total quantitites of radionuclides discharged into the atmosphere are summarized in Table 3 . The figures are similar to those of last year, and the releases resulted in a small population dose equivalent (see Table 11). 
Table 3. Total quantities discharged into the atmosphere, 1980.

\begin{tabular}{lc}
\hline \multicolumn{1}{c}{ Nuc 1ides } & Quantity Discharged $(C i\rangle$ \\
\hline Curium-243 & $1.7 \times 10^{-6}$ \\
Unidentified beta-gamma emitters & $1.0 \times 10^{-4}$ \\
Carbon-14 & 0.14 \\
Tritium & 48 \\
Iodine-125 & $4.2 \times 10^{-4}$ \\
\hline
\end{tabular}

All data from the general air sampling program were with in the range of normal background (Table 4). All measurements of atmospheric deposition at perimeter stations lie with in the range of norma $i$ background, al though small amounts of tritium were detected in rainfall collected with in the Laboratory boundary (Table 5).

The special air sampling program for ${ }^{14} \mathrm{C}$ and ${ }^{3} \mathrm{H}$ found detectable concentratioris of these nuclides (Table 6). Essentially, 100\% of the tritium released from LBL was discharged from the Building 75 stack. 
Table 4. Summary of air samples, 1980.

\begin{tabular}{|c|c|c|c|c|c|c|c|c|c|}
\hline & \multirow{3}{*}{$\begin{array}{l}\text { No. of } \\
\text { samples }\end{array}$} & \multicolumn{6}{|c|}{ Concentration, $10^{-15} \mu \mathrm{Cj} / \mathrm{ml}$} & \multicolumn{2}{|c|}{$\%$ of Standard ${ }^{a}$} \\
\hline & & \multicolumn{3}{|c|}{ Alpha } & \multicolumn{3}{|c|}{ Beta-Gamma } & \multirow{2}{*}{$\frac{\text { Alpha }}{\text { Avg. }}$} & \multirow{2}{*}{$\frac{\begin{array}{l}\text { Beta- } \\
\text { gamma }\end{array}}{\text { Avg. }}$} \\
\hline & & Avg. & Mir. & Max. & Avg. & Min. & $\operatorname{Max}$. & & \\
\hline$\frac{\text { On-site average }}{0: 10 \text { locations }}$ & 520 & $0.52 \pm 0.10$ & $<2$ & 6 & $24 \pm 4$ & $<80$ & 140 & 3 & 0.2 \\
\hline \multicolumn{10}{|l|}{ Perimeter Stations } \\
\hline Bldg. 88 & 53 & $1.18 \pm 0.32$ & $<2$ & 6 & $22 \pm 11$ & $<80$ & 240 & 6 & 0.2 \\
\hline B $1 \mathrm{dg} .90$ & 47 & $1.13 \pm 0.34$ & .2 & 5 & $32 \pm 12$ & $<80$ & 230 & 6 & 0.3 \\
\hline Panoramic Way & 52 & $0.96 \pm 0.31$ & $<2$ & 4 & $37 \pm 12$ & $<80$ & 240 & 5 & 0.4 \\
\hline 01 ympus Ga te & 52 & $0.82 \neq 0.30$ & $<2$ & 5 & $22 \pm 12$ & $<80$ & 170 & 4 & 0.2 \\
\hline \multicolumn{2}{|c|}{ Standard for comparison } & 20 & & & 10,000 & & & & \\
\hline
\end{tabular}

aSource: Reference 2. 
Table 5. Summary of atmospheric deposition, 1980.

\begin{tabular}{|c|c|c|c|c|c|c|c|c|}
\hline & \multicolumn{5}{|c|}{ Total deposition, $10^{-3} \mu \mathrm{Ci} / \mathrm{m}^{2}$} & \multicolumn{3}{|c|}{ Tritium in rainfall, ${ }_{\mu} \mathrm{Ci} / \mathrm{m} 2$ (as HTO) } \\
\hline & \multirow{2}{*}{$\begin{array}{l}\text { No. of } \\
\text { samples }\end{array}$} & \multicolumn{2}{|c|}{ Alpha } & \multicolumn{2}{|c|}{ Beta } & \multirow{2}{*}{$\begin{array}{l}\text { No. of } \\
\text { samples }\end{array}$} & \multirow[b]{2}{*}{ Avg. } & \multirow[b]{2}{*}{$\operatorname{Max} .^{a}$} \\
\hline & & Avg. & $\operatorname{Max}^{a}$ & Avg. & $\operatorname{Max} .^{a}$ & & & \\
\hline $\begin{array}{l}\text { On-Site } \\
\text { (9 locations) }\end{array}$ & 107 & 0.02 & 0.08 & 1.4 & 2.8 & 137 & $0.21 \pm 0.17$ & $2.8^{\mathrm{b}}$ \\
\hline $\begin{array}{l}\text { Per imeter } \\
\text { (4 locations) }\end{array}$ & 47 & 0.04 & 0.06 & 2.5 & 5.8 & 32 & $<0.18$ & $<0.6$ \\
\hline
\end{tabular}

No standards for comparison have been established

aHighest total for any one site.

$b_{A}$ lthough "on-site", this location is near the fence and representative of the area jusi outs ide the perimeter. The average tritium-in-rainfall concentration at this location (Bldg. 75 collector) was $5.4 \times 10^{-6} \mu \mathrm{Ci} / \mathrm{ml}, 0.2 \%$ of the drink ing water concentration guide (CG); the maximum observed concentration was $210 \times 10^{-6} \mu \mathrm{Ci} / \mathrm{ml}$ or $7 \%$ of the guideline (Ref. 2 ). 
Table 6. Summary of special air sampling, 1980.

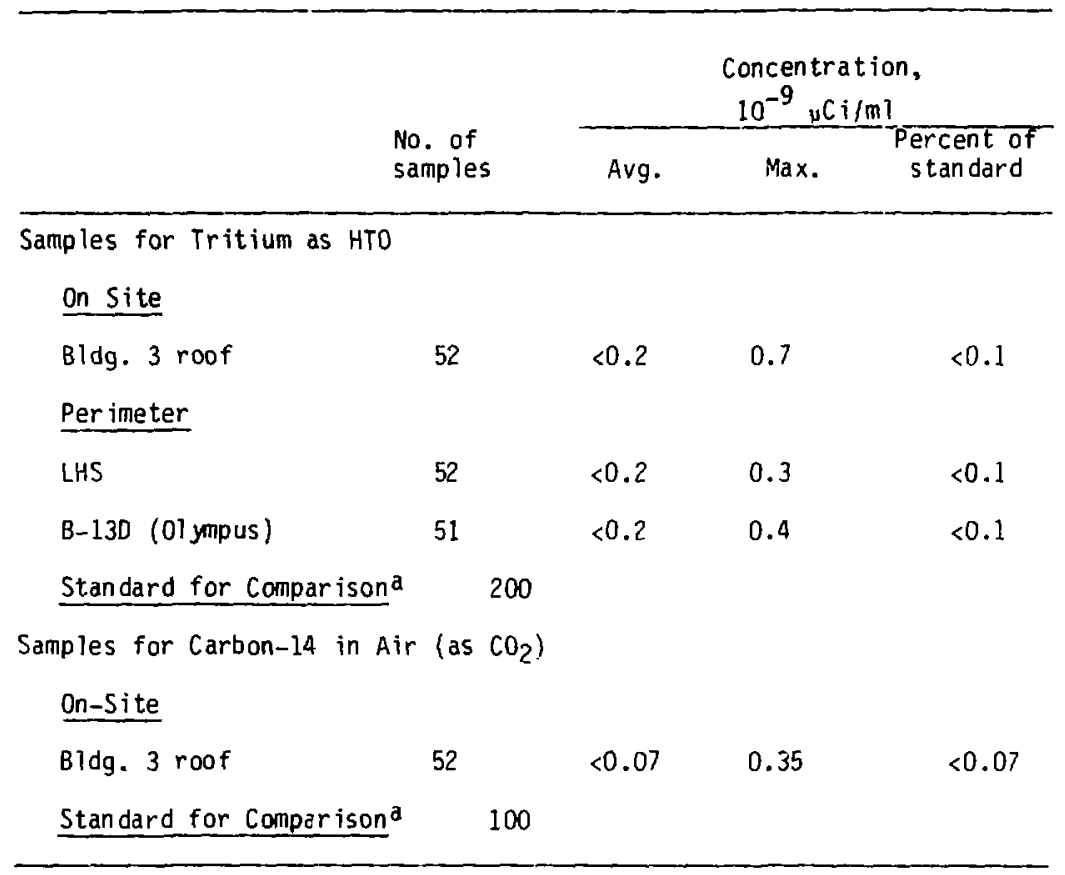

aSource: Reference 2. 


\section{WATERBORNE RADIONUCLIDES}

Rainwater, creek water, and sewage from LBL's two sewer outfalls (Fig. 1 - the Stramberry sanitary sewer is the southern site; Hearst is the western sewer) are analyzed for gross beta and alpha. Additionally. sewer effluent is analyzed for gross halogen (radioiodine) content; and rainwater, for tritium (the Building 75 tritium labeling facility does not release liquid effluent into the sewer or surface streams).

Sewer outfalls are sampled continuously, sample to flow ratios are designed to be between 10 and 20 parts per million, and composite samples are removed weekly. The five creek-sample points indicated in Figure 2 are sampled weely. A one-quart "grab" sample is taken from each site and anaiyzed for gross alpha and beta only.

The four perimeter environmental monitoring stations have 18-inch diameter cylindrical rainfall collectors on their roofs. During rainy months (generally 0ctober through May), rainwater is picked up morithly and analyzed for gross beta, alpha, and tritium. During the dry California summer, each collector is rinsed with a quart of tap water, and the rinse is analyzed for "dry deposition." The ten "other atmospheric sampling sites," alluded to in the air sampling section of this report, each contain a 18-inch diameter combination, rain/dry deposition collector, which is sampled on a monthly bas is in the same manner as the four perimeter environmental monitoring stations. 
Rain wich falls into the collector on the north side of Building 75 is analyzed on a storm-by-storm bas is for tritium, gross alpha, and gross beta. Tritium analys is of water samples is accomplished by liquid scintillation counting. Water samples are prepared for gross alpha and beta analysic by acidification $\left(\mathrm{HNO}_{3}\right)$ and evaporation into 2 -inch stainless steci planchettes. Organic residues not "wet ashed" by the nitric acid treatment are oxidized by flaming of the planchettes.

Since radioiodirie is driven out of the water sampler when ti:-y are acidified, aliquots of the sewer effluent samples are preserved for radioiodine analysis. The iodine contained in the samples is precipitated with silver using stable KI as a carrier. The iodine aliquots are filtered, and the filtrate is processed in the same manner as the acid $\left(\mathrm{HNO}_{3}\right)$ samples described earlier. After flaming the filtrate planchette, the filter containing any precipitated radioiodine is placed in the planchette and counted.

The prepared planchettes are weighed (each planchette is "tared" before sample processing) and counted in an automatic thin-window, low background, gas-proportional counter for both gross beta and alpha. Since the samples are "thick," self-absorption is computed based upon areal sample density which is the sample weight divided by $20.26 \mathrm{~cm}^{2}$, the area of the planchette (assuming an aloha energy of $5.2 \mathrm{MeV}$ and beta energy of $1 \mathrm{MeV}$ ).

Table 7 summarizes the 1980 data from the surface water and tap water sampling programs. These results are similar to those obtained in past years, and all lie with in the normal $r$ ange of background activity. There is no reason to suspect that any of the observed radioactivity originated from the laboratory. 
Table 7. Surface water and tap water samples, 1980.

\begin{tabular}{|c|c|c|c|c|c|c|c|}
\hline & \multirow{2}{*}{$\begin{array}{l}\text { No. of } \\
\text { samples }\end{array}$} & \multicolumn{4}{|c|}{ Concentration, $10^{-9} \mu \mathrm{Ci} / \mathrm{ml}$} & \multirow[b]{2}{*}{$\%$ of } & \multirow[b]{2}{*}{ Standard } \\
\hline & & \multicolumn{2}{|c|}{ Alpha } & \multicolumn{2}{|c|}{ Beta } & & \\
\hline \multicolumn{8}{|l|}{ On-Site Streams } \\
\hline $\begin{array}{l}\text { Blackberry } \\
\text { Lower Strawberry } \\
\text { Upper Str awberry } \\
\text { Average }\end{array}$ & $\begin{array}{l}52 \\
52 \\
52\end{array}$ & $\begin{array}{l}<0.4 \\
<0.3 \\
<0.3 \\
<0.2\end{array}$ & $\begin{array}{l}2.2 \\
3.2 \\
3.6\end{array}$ & $\begin{array}{l}1.6 \pm 0.1 \\
2.8 \pm 0.1 \\
1.7 \pm 0.1 \\
2.0 \pm 0.1\end{array}$ & $\begin{array}{l}3 \\
9 \\
4\end{array}$ & $\begin{array}{l}<1.3 \\
<1.0 \\
<1.0 \\
<0.7\end{array}$ & $\begin{array}{l}1.6 \\
0.8 \\
1.7 \\
2.0\end{array}$ \\
\hline \multicolumn{8}{|l|}{ off-Site Streams } \\
\hline $\begin{array}{l}\text { Claremont } \\
\text { Wildcat } \\
\text { Average }\end{array}$ & $\begin{array}{l}52 \\
52\end{array}$ & $\begin{array}{l}<0.5 \\
<0.2 \\
<0.3\end{array}$ & $\begin{array}{l}2.6 \\
2.0\end{array}$ & $\begin{array}{l}1.1 \pm 0.1 \\
1.2 \pm 0.1 \\
1.2=0.1\end{array}$ & $\begin{array}{l}2 \\
4\end{array}$ & $\begin{array}{l}<1.7 \\
<0.7 \\
<1.0\end{array}$ & $\begin{array}{l}1.1 \\
1.2 \\
1.2\end{array}$ \\
\hline Tap Water & 52 & $<0.1$ & 0.5 & $0.74 \pm 0.09$ & 3 & $<0.3$ & 0.7 \\
\hline Standard of Compari & & 30 & & 100 & & & \\
\hline
\end{tabular}

asource: Reference 2. 
Table 8 summarizes the sewage sampling data for 1980 . The average and maximum values listed for sewer beta concentrations reflect the weekly activity found in the hotter of the acid or radioiodine planchettes. LBL's historical release practices were maintained during 1980, and the Hearst siwage average beta concentration was about $0.7 \%$ of the DOE standard for beta discharges to sewers. ${ }^{2}$ The campus of the University of California discharges radioactive waste in to the Strawberry sewer above the point at which LBL monitors it. While the average Strawberry beta concentration for 1980 was significantly higher than the Hearst value, the figure represents about a fifteenfold decrease from the previous year (1979 average Strawberry beta concentration was $86 \%$ of the standard). NONRADIOACTIVE POLLUTANTS

The Laboratory does not carry out routine monitoring of airborne nonradioactive pollutants, although sewer sampling is cäried out for heavy metals. The analysis is achieved by atomic absorption.

Table 9 summarizes the sewer sampling data for heavy metals. 
Table 8. Summary of sewage sampling data, 1980.

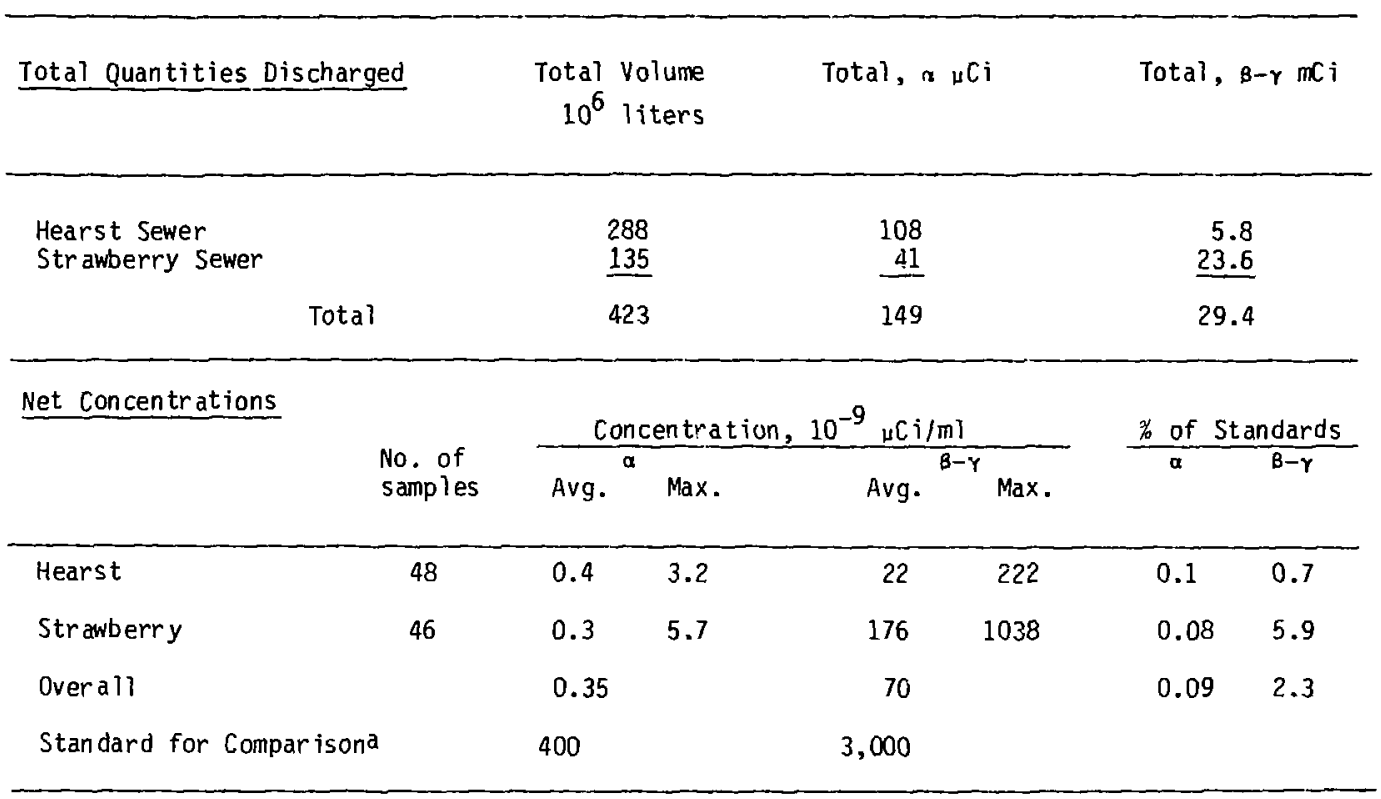

asource: Reference 2. 
Table 9. Summary of sewer sampling data for heavy metals, 1980.

\begin{tabular}{|c|c|c|c|c|c|c|c|c|c|}
\hline & \multicolumn{9}{|c|}{ Metals detected } \\
\hline & $\begin{array}{l}\text { No. of } \\
\text { Samples }\end{array}$ & Chromium & Copper & Zinc & Silver & Cadmium & Nickel & Iron & Lead \\
\hline \multicolumn{10}{|l|}{ Standard for comparison } \\
\hline $\begin{array}{l}\text { EBMUDa Timitation } \\
\text { on discharge }(\mathrm{mg} / \mathrm{l})\end{array}$ & & 2 & 5 & 5 & 1 & 1 & 5 & 100 & 2 \\
\hline \multicolumn{10}{|l|}{ Hearst Sewer } \\
\hline Average (mg/1) & 47 & 0.55 & 0.44 & 0.18 & 0.16 & $<0.1$ & 0.3 & 1.7 & 0.15 \\
\hline$\%$ of Standard & & 28 & 9 & 4 & 16 & $<10$ & 6 & 1.7 & 7.5 \\
\hline \multicolumn{10}{|l|}{ Strawberry Sewer } \\
\hline Average $(m g / 1)$ & 38 & 0.83 & 1.9 & 1.5 & $<0.1$ & $<0.11$ & 0.52 & 26 & 0.9 \\
\hline of Standard & & 42 & 38 & 30 & $<10$ & 11 & 10 & 26 & 45 \\
\hline
\end{tabular}

aEast Bay Municipal Utility District. 
POPULATION DOSE RESULTING FROM LBL OPERATIONS

ACCELERATOR-PRODUCED RADIATION

The Loi model for determining population dose equivalent from the maximum measured value of fence-post dose developed by Thomas ${ }^{3}$ assumes that fence post dose is uncorrelated with fluctuations in population. During 1980, both the Bevatron and the SuperHILAC were shutdown from August 11 to December 13, and the JuperHILAC did not start up again until March 2, 1980. However, because the period when both machines were operating included a significarit fraction of the summer when student/faculty populations were low and because most of the "down time" occurred when student/ facility populations were normal (fall, winter), the dose to the population, if calculated "naively" (i.e., ignoring the problem of down time), should be conservative.

The model's expression relating population dose equivalent, $M$, to maximum measured fence post dose is:

$$
M \leq 1,000 H_{0}[1-0.56 f]
$$

(where $f=$ fraction of the fence post dose contributed by the SuperHILAC and/or the 88-inch cyclotron). In 1980, the 01 ympus Gate monitoring station recorded the maximum fence post dose which was contributed equally by the SuperHILAC and the Bevatron. Thus, we use the 0lympus Gate Manitoring System data (Table 2) as our $H_{0}$ in $E q$. (1) above and $f=0.5$. Substituting the foregoing in Eq. (1),

$$
M \leq 1,000 \times 0.004[1-0.056(0.5)]
$$


we find the population dose attributable to accelerator operation to be

$$
M \leq 2.9 \text { man rem for } 1980
$$

\section{AIRBORNE RADIONUCLIDES}

The population dose equivalent resulting from airborne releases of radioactive nuclides $c$ an be determined from the moral developed by Cantelow. ${ }^{3}$ To provide more consistent reporting of these data, new values have besn calcu? U u llie curishunt, aR (man-rem $\mu$, urite releasec). Thase values, shown in Table 10, are based on MPC data listed in Ref. 2. These values replace those listed in Ref. 3, Table 16. Table 11 summarizes the total population dose equivalent caused by LBL operations.

Table 10. Population dose equivalent resulting from the release of one curie of radionuclides.

\begin{tabular}{|c|c|c|c|}
\hline Nuclide & $\begin{array}{c}M P C^{a} \\
(\mu \subset i / m l)\end{array}$ & $\left(\operatorname{Ren} \mathrm{m}^{3} \mathrm{Ci}^{\mathrm{a}} \mathrm{s}^{-1}\right)$ & ${ }_{(m a n-r e m / C i)}^{a_{R}^{a}}$ \\
\hline $\begin{array}{l}\text { Unidentified } \\
\text { a emitters }\end{array}$ & $2 \times 10^{-14}$ & $7.9 \times 10^{5}$ & $3 \times 10^{5}$ \\
\hline $\begin{array}{l}\text { Unidentified } \\
\beta \text { emitters }\end{array}$ & $1 \times 10^{-11}$ & $1.6 \times 10^{3}$ & $7 \times 10^{2}$ \\
\hline $3_{H}$ & $2 \times 10^{-7}$ & 0.079 & 0.03 \\
\hline${ }^{14} \mathrm{C}$ & $1 \times 10^{-7}$ & 0.16 & 0.07 \\
\hline $125_{I}$ & $8 \times 10^{-11}$ & 200.0 & 80.0 \\
\hline${ }^{243} \mathrm{~cm}$ & $2 \times 10^{-13}$ & $7.9 \times 10^{4}$ & $3 \times 10^{4}$ \\
\hline
\end{tabular}

aSource: Refercnce 2. 
Table 11. Population dose equivalent, 1980.

Contributing Factor

Population Dose

(man-rem)

Penetrating radiation from accelerator operation

Radionuc lide release:

${ }^{3} \mathrm{H}$

1.4

${ }^{14} \mathrm{C}$

0.01

$125 \mathrm{I}$

0.03

Unknown $B, y$ emitters

0.07

Cur ium-243

0.05

Tota 1

4.5

TRENDS - LBL ENVIRONMENTAL IMPACT

\section{ACCELERATOR-PRODUCED PENETRATING RADIATION}

Figures 3-6 show the annual accelerator-produced dose equivalent reported by the four perimeter environmental monitoring stations from the year they were established to date. During the past five years, the LBL accelerators have run heavy ions an increasing fraction of their operating schedule. Successful work in beam development has served to increase beam currents in recent years. However, concomitant improvements in beam optics have minimized stray radiation losses along the beam transport lines, resulting in smali annual population doses. 


\section{AIR AND WATERBORNE RADIONUCLIDES}

With the exception of occasional known releases, the atmospheric sampling program has yielded data over the past few years which are within the range of normal background. The surface water program always yields results within the $r$ ange of normal background. As no substantial changes in the quantities of radionuclides used are anticipated, no changes are expected in these abservations. Under the torms of its license, the University of California Berkeley campus has historically discharged radionuclides into the Strawberry sewer, complicating the analys is of LBL sewer sampling data. U.C. discharge practice was sharply curtailed during 1979. Indeed, 1980 seems to represent a dramatic change in University policy because on 1 y $0.7 \%$ of the 1978 gross beta activity was released to the Strabberry sewer last year. 


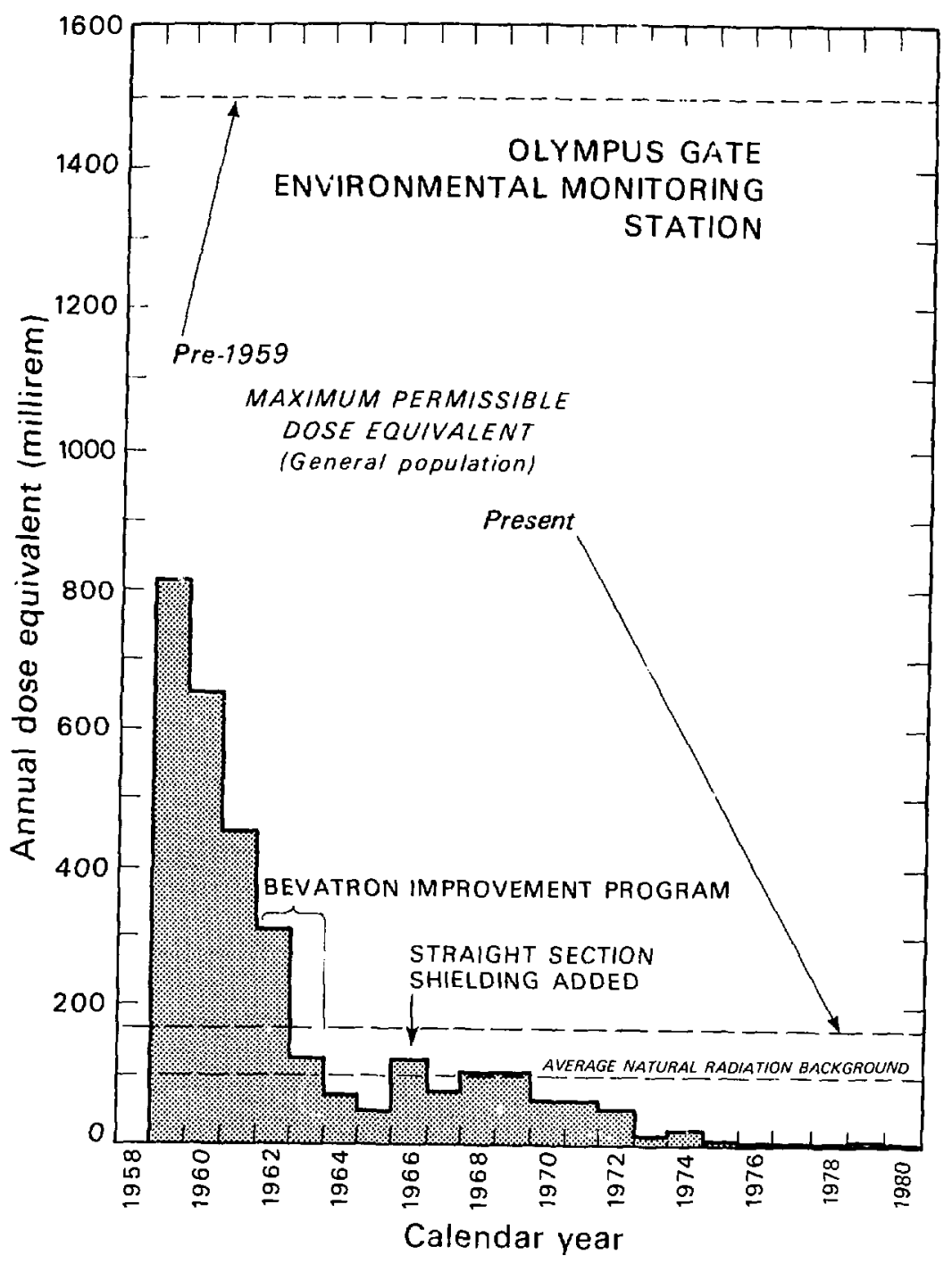

XBL 753.4766 E

FIGURE 3 


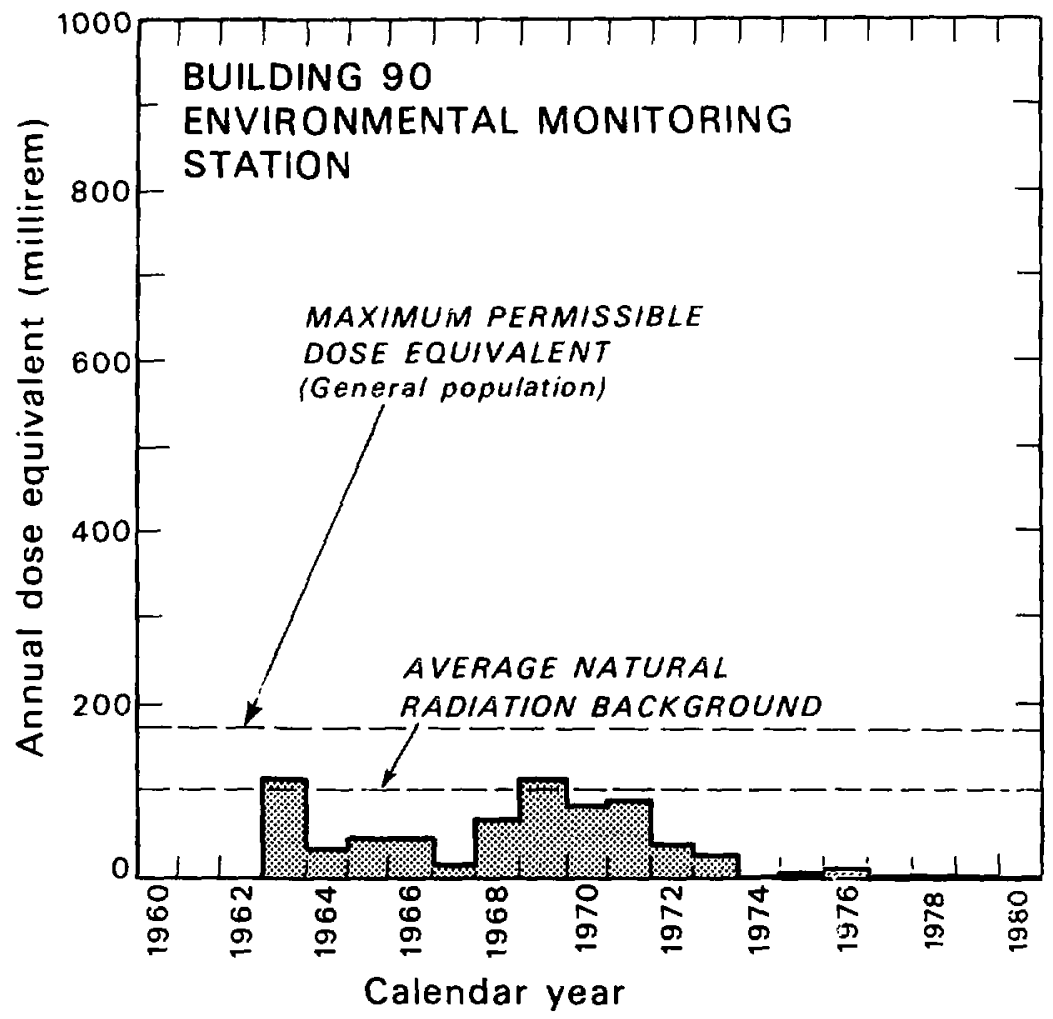

XBL 753-4768 D

FIGURE 4 


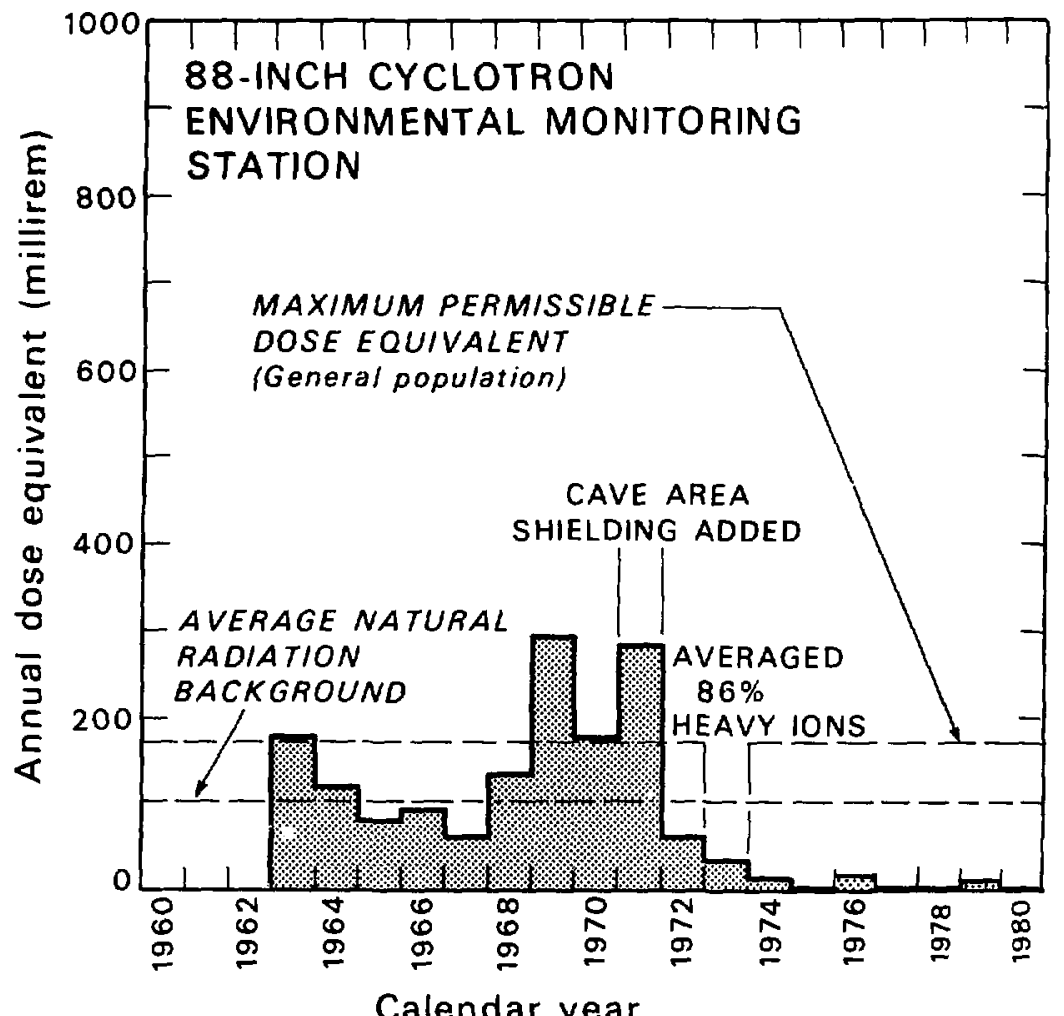

XBL 753-4767 D

FIGURE 5 


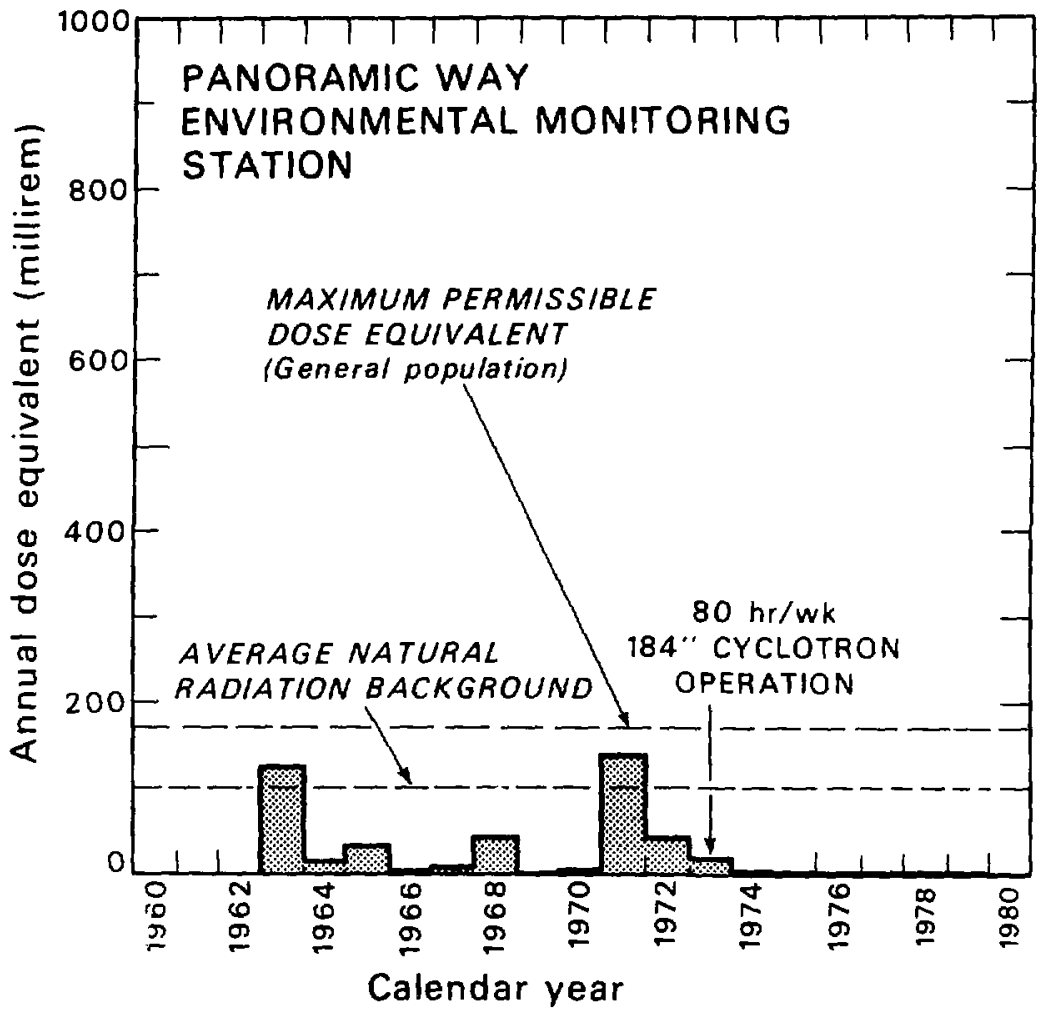

XBL 753-4769 D

FIGURE 6 
28

REFERENCES

1. U. S. Department of Energy, Effluent and Environmental Monitoring and Reporting, DOE Manual, Chapter 0513 (1974).

2. U. S. Department of Energy, Standards for Radiation Protection, DOE Manual, Chapter 0524 (1977).

3. Thomas, R. H. (ed.) The Environmental Surveillance Program of the Lawrence Berkeley Laboratory, LBL-4678 (1976).

4. Dak in, H. S., Stephens, L. D., Environmental Radiation Telemetry System, UCRL-16482 (1967). 
ANNUAL ENVIRONMENTAL MONITORING REPORT OF THE LAWRENCE BERKELEY LABORATORY

DISTRIBUTION LIST

NAME

D. A. Shirley

E. K. Hyde

E. L. ATpen

R. W. Birge

E. J. Cairns

J. Cerny

W. D. Hartsough

G. L. Pappas

H. A. Grunder

Environmental Hea 7 th and Safety Dept.

Lawrence Hall of Science

Technical Information

Bepartment

External: UC-41

DOE Headquarters

Thomas G. Frangos

Ed Keheley, Env., Safety, and Program

Support Division

EPA - Region IX

John T. Margan
NO. OF COP1ES

2

2

1

1

1

1

2

2

1

1

3

15

247

1

5

1 
DISTRIBUTION LIST (cont.)

NAME

Bureau of Radiological Health

F. Glenn Lynch

Chief of Env. Health

Jerry Winn, Director

City of San Francisco

Health Department

Water Quality Control Board

Bay Area Air Quality

Management Dist.
A. Hul1
D. Busick
L. Coulson
D. Jacobs
J. Sedlet
3. P. Cor ley
1
1
1
1
1
1

NO. OF COPIES

2

1

1

1

1

1 